\title{
Diabetes Mellitus in Neonates and Infants: Genetic Heterogeneity, Clinical Approach to Diagnosis, and Therapeutic Options
}

\author{
Oscar Rubio-Cabezas ${ }^{\mathrm{a}, \mathrm{b}}$ Sian Ellard ${ }^{\mathrm{b}}$ \\ ${ }^{a}$ Department of Paediatric Endocrinology, Hospital Infantil Universitario Niño Jesús, Madrid, Spain; \\ ${ }^{\mathrm{b}}$ Institute of Biomedical and Clinical Science, University of Exeter Medical School, Exeter, UK
}

\section{Key Words}

Neonatal diabetes · Monogenic diabetes of infancy .

Permanent neonatal diabetes · Transient neonatal

diabetes - Type 1 diabetes

\begin{abstract}
Over the last decade, we have witnessed major advances in the understanding of the molecular basis of neonatal and infancy-onset diabetes. It is now widely accepted that diabetes presenting before 6 months of age is unlikely to be autoimmune type 1 diabetes. The vast majority of such patients will have a monogenic disorder responsible for the disease and, in some of them, also for a number of other associated extrapancreatic clinical features. Reaching a molecular diagnosis will have immediate clinical consequences for about half of affected patients, as identification of a mutation in either of the two genes encoding the ATP-sensitive potassium channel allows switching from insulin injections to oral sulphonylureas. It also facilitates genetic counselling within the affected families and predicts clinical prognosis. Importantly, monogenic diabetes seems not to be limited to the first 6 months but extends to some extent into the second half of the first year of life, when type 1 diabetes is the more common cause of diabetes. From a scientific perspective, the identification of novel genetic aetiologies has provided important new knowledge regarding the development and function of the human pancreas.

Copyright $\odot 2013$ S. Karger AG, Basel
\end{abstract}

Presentation of diabetes within the first year of life was first reported in 1789 [1]. The fact that most cases occurred predominantly in the first and last quarters of the first year, suggesting some aetiologic heterogeneity in these patients, was recognized over 50 years ago [2] but did not receive adequate attention until recently [3]. The rarity of the condition, with an overall estimated incidence of less than 2 cases per 100,000 infants [4, 5], might have played a role in this lack of awareness. However, the enormous amount of novel information gathered since the publication of the human genome a decade ago has increased our understanding of the pathophysiology of this rare condition and had a huge impact on routine clinical care for diabetic infants.

\section{Diabetes Mellitus in Infants: The Basics}

Only a few years ago, type 1 diabetes (T1D) was considered the main form of diabetes presenting in infancy, and the term 'neonatal diabetes' (NDM) was reserved for diabetes presenting within the first 4-6 weeks of life [6].

\section{Type 1 Diabetes}

T1D is a T cell-mediated autoimmune disease that results from a selective destruction of the pancreatic insulin-producing $\beta$-cells and is the most common cause of diabetes in children, accounting for over $95 \%$ of cases [7].

\begin{tabular}{ll}
\hline KARGER & $\begin{array}{l}\text { (c) 2013 S. Karger AG, Basel } \\
1663-2818 / 13 / 0803-0137 \$ 0.00 / 0\end{array}$ \\
$\begin{array}{l}\text { E-Mail karger@karger.com } \\
\text { www.karger.com/hrp }\end{array}$ & $\begin{array}{l}\text { This is an Open Access article licensed under the terms of } \\
\text { the Creative Commons Attribution 3.0 Unported license } \\
\text { (CC BY 3.0) (www.karger.com/OA-license-WT), appli- } \\
\text { cable to the online version of the article only. }\end{array}$
\end{tabular}

Prof. Sian Ellard, PhD, FRCPath

Department of Molecular Genetics, Royal Devon and Exeter NHS Foundation Trust Barrack Road

Exeter EX2 5AD (UK)

E-Mail sian.ellard@nhs.net 


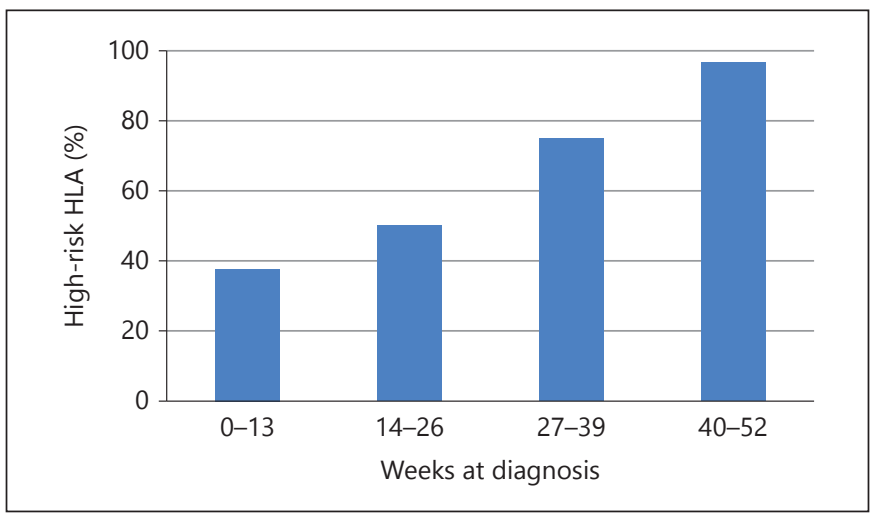

Fig. 1. HLA distribution in infants diagnosed with diabetes mellitus under 1 year of age. Modified from Edghill et al. [25].

The disease results from a combination of genetic predisposition and a number of potential environmental factors. Genome-wide association studies have identified over 40 loci contributing to T1D [8], but allelic variation within the HLA class II region in the major histocompatibility complex on chromosome $6 \mathrm{p} 21.3$ contributes about $50 \%$ of the inherited risk [9]. The earlier the clinical onset of the disease, the stronger the genetic susceptibility, especially when diabetes presents before 2 years of age [10]. However, when the HLA haplotype distribution was studied in infants diagnosed with diabetes within the first year of life, the distribution in infants presenting at or after 7 months was similar to older T1D patients (95\% positive for high-risk HLA), whereas younger patients diagnosed before 6 months were similar to control subjects (40\% positive; fig. 1 ) $[3,11]$.

The environmental triggers that initiate pancreatic $\beta$-cell destruction in T1D remain largely unknown. Pancreatic autoantibodies are a hallmark of the underlying autoimmune process and their presence long precedes clinical diagnosis of T1D $[12,13]$, but prospective studies in newborns with HLA-defined genetic high risk for T1D have shown that autoimmunity does not usually evolve rapidly enough to cause clinical T1D in the first months of life [14-16]. In keeping with this, infants diagnosed with diabetes before 6 months of age were less likely to be antibody positive than infants diagnosed later (15 vs. 65\%) [3]. Even though autoimmune diabetes is rare in very young infants [3], it is now accepted that FOXP3 mutations, and not T1D, will account for most of these cases [17].

Almost two thirds of the infants diagnosed in the first 6 months were born small for gestational age, in contrast to $15 \%$ of those presenting between 6 and 12 months [3]. On the other hand, a recent meta-analysis has shown that higher birthweights are associated with a mildly increased risk of developing T1D [18]. Since insulin exerts potent growth-promoting effects during intrauterine development [19], a low birthweight in infants diagnosed with diabetes soon after birth might reflect reduced insulin secretion by the foetal pancreas due to $\beta$-cell dysfunction in utero.

\section{Monogenic, Non-Type 1 Diabetes}

According to the information displayed above, clinical presentation of polygenic autoimmune T1D within the first 6 months of life is rare. The majority of these patients will have a monogenic form of diabetes [20].

Over the last few years, the age limit to consider a nonautoimmune, monogenic cause has changed from the first 30-45 days of life [6] to 3 months, then 6 months [21] and now 9 months [22]. Monogenic diabetes of infancy has been suggested to be a more appropriate name than NDM [21], but the latter is still extensively used and preferred by many authors. Approximately $50 \%$ of the NDM patients will require lifelong treatment to control hyperglycaemia (permanent NDM, PNDM). In the remaining patients, diabetes will remit within a few weeks or months (transient NDM, TNDM), although it might relapse later in life. In both cases, diabetes is more frequently isolated, but some cases show a variety of associated extra-pancreatic clinical features pointing to a particular gene, which may help guide genetic testing (table 1) [20].

\section{Genetic Heterogeneity in Infancy-Onset Monogenic Diabetes}

NDM is genetically heterogeneous, with at least 20 different causal genes identified to date (table 1). The vast majority of the monogenic causes of NDM result in impaired insulin secretion rather than insulin sensitivity [23]. From an aetiopathogenic perspective, insulin deficiency appears as a result of one of three alternative mechanisms: either impaired development or function of $\beta$-cells, and progressive $\beta$-cell destruction (table 1 ). Whilst the genetic basis of TNDM has been mostly uncovered, with three genetic abnormalities accounting for the majority of patients [24], the gene mutated in up to $40 \%$ of PNDM cases remains unknown [25].

\section{Permanent Neonatal Diabetes}

Activating mutations in either the KCNJ11 or ABCC8 genes encoding the two subunits (Kir6.2 and SUR1, respectively) of the ATP-sensitive potassium $\left(\mathrm{K}_{\mathrm{ATP}}\right)$ chan- 
Table 1. Monogenic subtypes of neonatal and infancy-onset diabetes mellitus

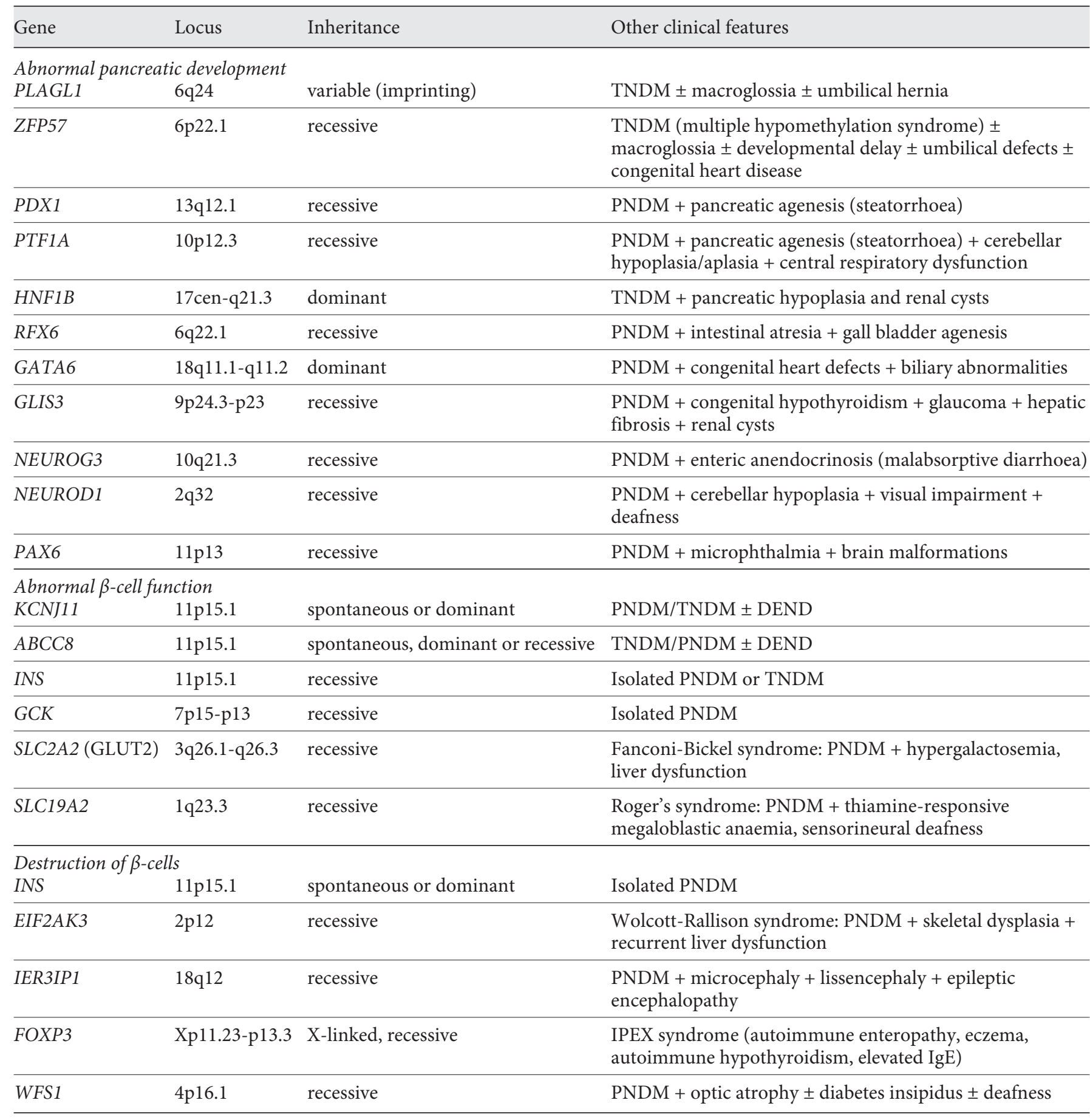

nel of the $\beta$-cell membrane, prevent insulin secretion in response to hyperglycaemia and can cause both PNDM and TNDM [26-28]. KCNJ11 mutations are more frequent, and most patients have PNDM rather than TNDM. In contrast, mutations in $A B C C 8$ cause TNDM more fre- quently. Consistent with the expression of $\mathrm{K}_{\mathrm{ATP}}$ channels in neurons [29], about $20 \%$ of probands with KCNJ11 mutations present with associated neurological symptoms [30]. The most severe defect includes marked developmental delay and early-onset epilepsy, and has been 


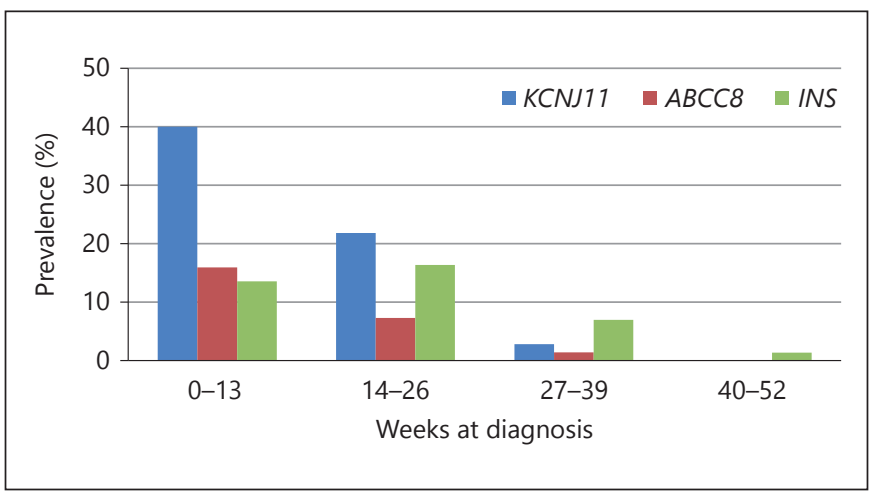

Fig. 2. Prevalence of the three more common genetic subtypes of monogenic diabetes during the first year of life. Redrawn from Rubio-Cabezas et al. [22].

\section{Non-consanguineous parents $(n=700)$}

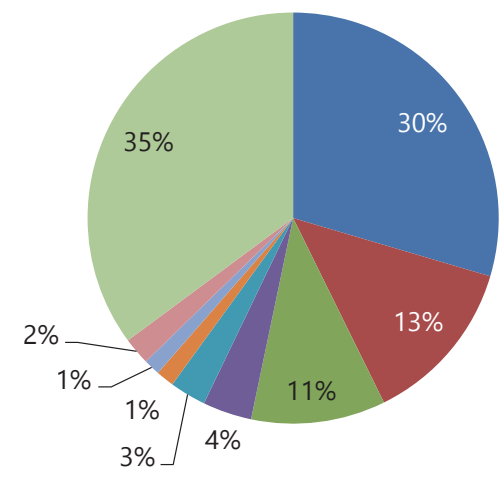

Consanguineous parents $(n=218)$

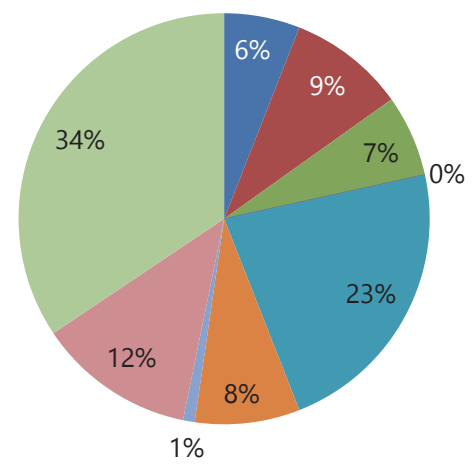

KCNJ11

INS

$A B C C 8$

- GATA6

EIF2AK3

- GCK

FOXP3

Others

No mutation

Fig. 3. Influence of parental consanguinity on the genetic aetiology in the Exeter cohort of PNDM. Updated from Rubio-Cabezas et al. [72].

called DEND syndrome. An intermediate DEND syndrome characterized by NDM and less severe developmental delay without epilepsy is more common. Neurological features can also present in patients with mutations in $A B C C 8$ but are less frequent and usually milder (language delay and dyspraxia, mainly) [28, 31]. There are no significant clinical differences between these two subtypes of monogenic diabetes regarding the severity of intrauterine growth retardation (median birthweight around -1.5 SDS for gestational age) or the median age at diabetes presentation ( $4-8$ weeks) $[24,25]$. Diabetes is diagnosed within the first 6 months in the vast majority of patients, although they can occasionally present beyond 6 months [22] (see fig. 2). More than $90 \%$ of patients with activating mutations in the $\mathrm{K}_{\mathrm{ATP}}$ channel genes can transfer from insulin to high-dose sulphonylureas, with improved glycaemic control and decreased risk of hypoglycaemia [32-34]. Preliminary data also suggest that glibenclamide might partially improve or even prevent some of the associated neurological symptoms [35-37].

Heterozygous coding mutations in the proinsulin gene (INS) are the second most common cause of isolated PNDM $[25,38-40]$. The mutation usually results in accumulation of a misfolded proinsulin molecule in the endoplasmic reticulum (ER), leading to ER stress and $\beta$-cell apoptosis [40]. The severity of the intrauterine growth retardation in patients with INS mutations is similar to that of patients with $\mathrm{K}_{\mathrm{ATP}}$ channel mutations, but diabetes tends to present slightly later [25], even in late infancy or childhood $[22,39,41]$. Since there is a progressive $\beta$-cell death, insulin is the only treatment currently available.

Mutations in the $\mathrm{K}_{\mathrm{ATP}}$ channel genes and the proinsulin gene (INS) account for at least 50-75\% of infancy-onset permanent monogenic diabetes in outbred populations [22, 25, 42, 43]. However, parental consanguinity exerts a strong influence on both the prevalence and the genetic aetiology of NDM, with mutations in EIF2AK3 being the commonest known genetic cause (fig. 3) [44, 45]. All mutations reported to date in KCNJ11 and most mutations in ABCC 8 and INS are heterozygous and, hence, dominantly acting. These mutations frequently appear de novo, and consequently there is no positive family history of diabetes suggesting a genetic disorder. Therefore, these patients cannot be clearly distinguished from those with early-onset T1D just on clinical grounds. In contrast, some mutations in ABCC8 and INS, and all mutations in EIF2AK3 -causing Wolcott-Rallison syndrome-, $G C K$, and other genes less frequently involved in NDM are homozygous or compound heterozygous, indi- 
cating a recessive inheritance. The risk of developing one of these recessive subtypes of NDM is therefore increased when parental consanguinity is present. However, $\mathrm{K}_{\mathrm{ATP}}$ channel mutations account for a minority of consanguineous cases, indicating that the likelihood of transitioning from insulin onto oral sulphonylureas is significantly lower when parents are related.

\section{Transient Neonatal Diabetes}

The majority of cases ( 70\%) are linked to 3 different abnormalities in an imprinted region on chromosome 6q24 ultimately leading to overexpression of a PLAGL1: paternal duplication, paternal uniparental disomy, and abnormal methylation of the maternal allele [46, 47]. The latter methylation defect sometimes arises in the context of a generalized hypomethylation syndrome [48] secondary to biallelic mutations in ZFP57, a gene involved in the regulation of DNA methylation [49].

Patients with 6q24 abnormalities are born with moderate intrauterine growth retardation (average birthweight: $1,930 \mathrm{~g}$ ) and usually develop severe non-ketotic hyperglycaemia during the first week of life $[47,50]$. Despite the severity of the initial presentation, diabetes remits in the majority of patients by a median age of 12 weeks. During remission, transient hyperglycaemia may occur during intercurrent illnesses [51]. Diabetes tends to relapse around puberty but may do so from the age of 4 years. Clinically, relapse resembles early-onset type 2 diabetes. Insulin therapy is not always necessary as diabetes may respond to oral sulphonylureas but, if needed, insulin doses required are lower than in patients with T1D.

Genetic counselling for families with 6q24 TNDM depends on the underlying molecular mechanism. Uniparental disomy of chromosome 6 is generally sporadic and therefore the risk of recurrence in siblings and offspring is low. For paternal duplication of the 6q 24 region, males have a $50 \%$ chance of transmitting the mutation and the disease to their children. In contrast, females will pass on the duplication, but their children will not develop the disease, which may recur instead in the next generation as their asymptomatic sons pass on the molecular defect to their own children. Methylation defects are usually sporadic, but mutations in ZFP57 show an autosomal recessive inheritance, and hence the recurrence risk is $25 \%$ for siblings and almost negligible for the offspring of an affected patient.

Activating mutations in any of the genes (KCNJ11 and $A B C C 8$ ) encoding the two subunits (Kir6.2 and SUR1, respectively) of the $\mathrm{K}_{\mathrm{ATP}}$ channel of the $\beta$-cell membrane

Neonatal and Infancy-Onset Monogenic Diabetes Mellitus account for most of the remaining cases of TNDM [27, 28]. Compared to patients with 6q24 abnormalities, TNDM patients with activating $\mathrm{K}_{\mathrm{ATP}}$ channel mutations show milder intrauterine growth retardation and are diagnosed later, suggesting that the prenatal insulin deficiency is less severe. In addition, diabetes tends to remit later and relapses sooner [24].

\section{Recent Identification of New Genetic Subtypes}

Since NDM was last reviewed in this journal in 2007 [52], a number of new genes underlying this diagnosis have been identified. The most relevant one from a clinical perspective was undoubtedly INS, the gene encoding insulin [38], which accounts for about $10-15 \%$ of NDM cases and is the second most common cause after activating mutations in the $\mathrm{K}_{\mathrm{ATP}}$ channel genes [25, 39, 40, 42]. Since INS is mostly expressed in pancreatic $\beta$-cells, the affected patients do not show any extrapancreatic features. In addition to causing NDM, INS mutations may present acutely after the first 6 months of age and even beyond the age of one year, when monogenic diabetes becomes exceedingly rare [41]. Furthermore, up to $70 \%$ of the mutations are de novo, so that family history of early-onset diabetes is lacking. It is therefore likely that some patients with an INS mutation are clinically indistinguishable from early-onset T1D. In these cases, routine measurement of pancreatic autoantibodies in young children with diabetes may be a helpful tool to identify candidates for genetic testing [53].

A second area where major advances have recently been achieved is syndromic, early-onset diabetes, i.e. diabetes associated with varied extrapancreatic features, which represents about $10 \%$ of cases. Most of the newly identified genetic causes are transcription factors important for pancreatic development at different stages (table 1). Many were suggested as candidate genes from mouse knockout models. The first novel aetiology to be identified by next generation sequencing technology was GATA6 haploinsufficiency [54]. De novo mutations were identified by exome sequencing of affected proband/unaffected, unrelated parent trios before Sanger sequencing in a wider cohort showed that heterozygous GATA6 mutations are the most common cause of pancreatic agenesis [54]. The phenotypic spectrum has recently been extended with the description of GATA6 mutations in patients with PNDM, TNDM or adult-onset diabetes [55]. Cardiac malformations are present in most cases.

When the mutated transcription factor is normally expressed early in development (for instance, RFX6 or 
GATA6), both endocrine and exocrine lineages are involved, and the affected patient shows some degree of pancreatic hypoplasia and exocrine dysfunction, in addition to the associated extrapancreatic features secondary to the extrapancreatic expression of the respective gene [54-56]. On the contrary, when the expression of the transcription factor is limited to the endocrine pancreas (i.e. NEUROG3, NEUROD1, PAX6), pancreatic hypoplasia and exocrine dysfunction are lacking [57-59]. Importantly, the presence of extrapancreatic features does not necessarily indicate a developmental disorder. This is exemplified by mutations in IER3IP1, which cause NDM plus lissencephaly and other neurological abnormalities by inducing ER-associated apoptosis [60].

Despite the above-referenced recent advances, up to $40 \%$ of patients with NDM remain without a molecular genetic diagnosis [25], most of them not showing any associated extrapancreatic clinical manifestations, which suggests that other genes are yet to be discovered.

\section{Clinical Approach to Genetic Testing in Infancy-Onset Diabetes}

Reaching a specific molecular diagnosis in patients with suspected monogenic diabetes has important clinical consequences as it may influence diabetes treatment and define the prognosis in the affected subject as well as in other family members. Whilst genetic testing confirms or excludes a diagnosis of monogenic diabetes with both high sensitivity and high specificity, molecular studies are expensive and time-consuming, and some criteria must be used to select candidates for genetic testing.

Age at diabetes onset can be considered the cornerstone criterion since most infants diagnosed before 6 months will have monogenic diabetes [20]. It has recently been demonstrated that genetic testing for mutations in the $\mathrm{K}_{\text {ATP }}$ channel genes in these patients is costeffective [61] and therefore both genes should be screened in the first place. If no mutations are identified, INS is the next gene to investigate. Testing for $6 \mathrm{q} 24$ abnormalities should be considered in case where diabetes has already remitted at the time of referral or if the patient was born with significant low birthweight, is still aged $<3-6$ months (before possible remission), and diabetes presented within the first week of life. If this is also negative, further testing may be guided by additional clinical criteria.

The history and physical examination, either of the patient or other affected family members, are the best and cheapest tools available for this purpose [62]. Associ- ated extra-pancreatic clinical features might point to specific genes, most of which (apart from $H N F 1 B$ and GATA6), cause autosomal recessive disorders (as shown in table 1). Parental consanguinity also suggests an autosomal recessive syndrome. However, absence of known consanguinity does not exclude autosomal recessive inheritance, especially in populations with a high consanguinity rate.

Patients presenting with diabetes during the first 6 months of life tend to be small for gestational age at birth $[3,63]$. However, the degree of intrauterine growth retardation among patients with different subtypes of NDM varies widely. Patients unable to produce any insulin both prenatally and postnatally due to pancreatic agenesis or biallelic mutations in GCK or INS show lower birthweights, usually below -3 SDS for gestational age [64-66], compared to patients with heterozygous INS mutations or Wolcott-Rallison syndrome where birthweight, although typically low, is usually above -2 SDS for gestational age $[25,44]$. This is in keeping with the underlying mechanism causing NDM, with the latter two examples involving progressive destruction of normally developed $\beta$-cells and therefore prenatal insulin secretion being relatively spared.

Some laboratory tests may also prove useful. The size of the pancreas and the exocrine function may be evaluated by a number of imaging and biochemical tests - abdominal US, CT or MRI scans, and faecal fat or elastase, respectively. In selected patients, other tests should be considered including, but not limited to, liver and kidney function tests, X-ray bone survey, audiogram, echocardiogram and/or brain MRI. Positive autoantibodies to $\beta$-cells may indicate IPEX syndrome when identified in a male patient presenting with NDM soon after birth or, alternatively, suggest very early-onset T1D in a patient (male or female) who developed diabetes slightly before 6 months of age.

It is important to keep in mind that some infants presenting with diabetes after 6 months will also have monogenic diabetes, especially when pancreatic autoantibodies are negative. If there are no associated clinical features, screening for INS mutations followed by $\mathrm{K}_{\mathrm{ATP}}$ channel genes testing should be considered. Apart from WolcottRallison syndrome, late infancy-onset diabetes is exceedingly rare in other forms of syndromic monogenic diabetes.

The advent of next-generation sequencing technologies brings the possibility of simultaneous testing for all known NDM genes in a single assay [67], and this increases the diagnostic rate for patients with NDM. 


\section{Options for Treatment and Management}

Early insulin administration is acutely required in most infants with newly diagnosed diabetes to treat or prevent acute metabolic decompensation and to allow weight gain [68]. Caloric and glucose restriction in an attempt to avoid or delay insulin therapy should be strongly discouraged. Insulin treatment in infants is always challenging and must be carefully designed in keeping with their nutritional management and frequent glucose monitoring.

Insulin can be provided by multiple daily injections or continuous subcutaneous infusion [69]. It may be necessary to use diluted insulin to meet very low insulin requirements and minimize the risk of hypoglycaemia. In infants with parenteral nutrition or continuous enteral feeding, the total daily dose of insulin should be given as basal infusion. As in healthy infants, breastfeeding is recommended, and its frequency influences insulin requirements. With more than 6 breast feeds per day, high basal insulin substitution with very low mealtime boluses allows for a stable blood glucose levels. When more intermittent oral feeding is started, increased insulin requirements associated to meals require increased doses of rapid-acting insulin analogues and the basal insulin has to be reduced accordingly, to $30-50 \%$ of total daily dose in infants with multiple daily injections or to $10-30 \%$ with continuous subcutaneous infusion. Since food intake in infants is frequently unpredictable, immediate postprandial insulin administration might be considered in certain circumstances. Extra-slowly-absorbed complex carbohydrates such as corn starch may be given at bedtime to prevent nocturnal hypoglycaemia.

Most patients with activating mutations in $\mathrm{KCNJ11}$ or $A B C C 8$ can be successfully switched from insulin to oral sulphonylurea $[32,33]$, with a marked improvement in metabolic control. Transfer protocols are available at www.diabetegenes.org. The required doses of sulphonylurea are usually high, especially in patients with neuro- logical features, but tend to decrease over time irrespective of the mutation. Long-term follow-up has revealed persistent efficacy and safety [34]. The only side effects reported to date are transient diarrhoea at transfer [70] and staining of the teeth in the longer term [71].

Patients with agenesis of the pancreas require pancreatic enzyme supplements in addition to insulin treatment.

\section{Conclusions}

When a newborn or infant presents with diabetes, both clinicians and families face a highly complex situation. Reaching a molecular diagnosis confirms the genetic subtype, predicts the prognosis and possible development of extra-pancreatic features, and determines the risk of diabetes in future siblings/offspring. The most dramatic impact is for those patients with a $\mathrm{K}_{\mathrm{ATP}}$ channel mutation who are able to transfer from insulin injections to sulphonylurea tablets and achieve improved glycaemic control. More than 20 different causal genes have now been identified, with many new aetiologies discovered through a combination of homozygosity/sequencing analysis of candidate genes suggested from mouse knockout studies. Exome sequencing has revealed GATA6 haploinsufficiency as the most common cause of pancreatic agenesis, and the expectation is that genome-wide analysis by next generation sequencing will rapidly uncover additional new causal genes to assist in the diagnosis and clinical management of NDM.

\section{Acknowledgements}

O.R.C. holds a 'Miguel Servet' Research Fellowship funded by the Instituto de Salud Carlos III (CP11/00263). S.E. is a Wellcome Trust Senior Investigator and is employed as a core member of staff within the NIHR-funded Exeter Clinical Research Facility.

\section{References}

1 Schwartzman J, Crusius ME, Beirne DP: Diabetes mellitus in infants under one year of age; report of a case and review of the literature. Am J Dis Child 1947;74:587-606.

- Keidan SE: Transient diabetes in infancy. Arch Dis Child 1955;30:291-296.

-3 Iafusco D, Stazi MA, Cotichini R, Cotellessa M, Martinucci ME, Mazzella M, Cherubini V, Barbetti F, Martinetti M, Cerutti F, Prisco F,
Early Onset Diabetes Study Group of the Italian Society of Paediatric Endocrinology and Diabetology: Permanent diabetes mellitus in the first year of life. Diabetologia 2002; 45:798-804, erratum in Diabetologia 2003;46: 140.

-4 Rosenbauer J, Herzig P, von Kries R, Neu A, Giani G: Temporal, seasonal, and geographical incidence patterns of type I diabetes mellitus in children under 5 years of age in Germany. Diabetologia 1999;42:1055-1059.

5 Grulich-Henn J, Wagner V, Thon A, Schober E, Marg W, Kapellen TM, Haberland H, Raile K, Ellard S, Flanagan SE, Hattersley AT, Holl RW: Entities and frequency of neonatal diabetes: data from the diabetes documentation and quality management system (DPV). Diabet Med 2010;27:709-712.
Neonatal and Infancy-Onset Monogenic Diabetes Mellitus
Horm Res Paediatr 2013;80:137-146 DOI: $10.1159 / 000354219$ 
6 von Mühlendahl KE, Herkenhoff H: Longterm course of neonatal diabetes. N Engl J Med 1995;333:704-708.

7 Porter JR, Barrett TG: Acquired non-type 1 diabetes in childhood: subtypes, diagnosis, and management. Arch Dis Child 2004;89: 1138-1144.

8 Concannon P, Rich SS, Nepom GT: Genetics of type 1A diabetes. N Engl J Med 2009;360: 1646-1654.

-9 Erlich H, Valdes AM, Noble J, Carlson JA, Varney M, Concannon P, Mychaleckyj JC, Todd JA, Bonella P, Fear AL, Lavant E, Louey A, Moonsamy P: Type 1 Diabetes Genetics Consortium. HLA DR-DQ haplotypes and genotypes and type 1 diabetes risk: analysis of the type 1 diabetes genetics consortium families. Diabetes 2008;57:1084-1092.

10 Komulainen J, Kulmala P, Savola K, Lounamaa R, Ilonen J, Reijonen H, Knip M, Akerblom HK: Clinical, autoimmune, and genetic characteristics of very young children with type 1 diabetes. Childhood Diabetes in Finland (DiMe) Study Group. Diabetes Care 1999;22:1950-1955.

11 Edghill EL, Dix RJ, Flanagan SE, Bingley PJ, Hattersley AT, Ellard S, Gillespie KM: HLA genotyping supports a nonautoimmune etiology in patients diagnosed with diabetes under the age of 6 months. Diabetes 2006;55:18951898.

12 Schatz D, Krischer J, Horne G, Riley W, Spillar R, Silverstein J, Winter W, Muir A, Derovanesian D, Shah S, et al: Islet cell antibodies predict insulin-dependent diabetes in United States school age children as powerfully as in unaffected relatives. J Clin Invest 1994;93:2403-2407.

-13 Wenzlau JM, Juhl K, Yu L, Moua O, Sarkar SA, Gottlieb P, Rewers M, Eisenbarth GS, Jensen J, Davidson HW, Hutton JC: The cation efflux transporter ZnT8 (Slc30A8) is a major autoantigen in human type 1 diabetes. Proc Natl Acad Sci USA 2007;104:17040-17045.

14 Lindberg B, Ivarsson SA, Landin-Olsson M, Sundkvist G, Svanberg L, Lernmark A: Islet autoantibodies in cord blood from children who developed type I (insulin-dependent) diabetes mellitus before 15 years of age. Diabetologia 1999;42:181-187.

15 Achenbach P, Bonifacio E, Koczwara K, Ziegler AG: Natural history of type 1 diabetes. Diabetes 2005;54(suppl 2):S25-S31.

16 Kimpimäki T, Kupila A, Hämäläinen AM, Kukko M, Kulmala P, Savola K, Simell T, Keskinen P, Ilonen J, Simell O, Knip M: The first signs of beta-cell autoimmunity appear in infancy in genetically susceptible children from the general population: the Finnish Type 1 Diabetes Prediction and Prevention Study. J Clin Endocrinol Metab 2001;86:4782-4788.

17 Rubio-Cabezas O, Minton JA, Caswell R, Shield JP, Deiss D, Sumnik Z, Cayssials A, Herr M, Loew A, Lewis V, Ellard S, Hattersley AT: Clinical heterogeneity in patients with FOXP3 mutations presenting with permanent neonatal diabetes. Diabetes Care 2009;32:111-116.
18 Cardwell CR, Stene LC, Joner G, Davis EA, Cinek O, Rosenbauer J, Ludvigsson J, Castell C, Svensson J, Goldacre MJ, Waldhoer T, Polanska J, Gimeno SG, Chuang LM, Parslow RC, Wadsworth EJ, Chetwynd A, Pozzilli P, Brigis G, Urbonaite B, Sipetić S, Schober E, Ionescu-Tirgoviste C, de Beaufort CE, Stoyanov D, Buschard K, Patterson CC: Birthweight and the risk of childhood-onset type 1 diabetes: a meta-analysis of observational studies using individual patient data. Diabetologia 2010;53:641-651.

19 Gicquel C, Le Bouc Y: Hormonal regulation of fetal growth. Horm Res 2006;65(suppl 3):28-33.

20 Hattersley A, Bruining J, Shield J, Njolstad P, Donaghue KC: The diagnosis and management of monogenic diabetes in children and adolescents. Pediatr Diabetes 2009;10(suppl 12):33-42.

21 Massa O, Iafusco D, D’Amato E, Gloyn AL, Hattersley AT, Pasquino B, Tonini G, Dammacco F, Zanette G, Meschi F, Porzio O, Bottazzo G, Crinó A, Lorini R, Cerutti F, Vanelli M, Barbetti F, Early Onset Diabetes Study Group of the Italian Society of Pediatric Endocrinology and Diabetology: KCNJ11 activating mutations in Italian patients with permanent neonatal diabetes. Hum Mutat 2005; 25:22-27.

-22 Rubio-Cabezas O, Flanagan SE, Damhuis A, Hattersley AT, Ellard S: K(ATP) channel mutations in infants with permanent diabetes diagnosed after 6 months of life. Pediatr Diabetes 2012;13:322-325.

23 Murphy R, Ellard S, Hattersley AT: Clinical implications of a molecular genetic classification of monogenic beta-cell diabetes. Nat Clin Pract Endocrinol Metab 2008;4:200-213.

24 Flanagan SE, Patch AM, Mackay DJ, Edghill EL, Gloyn AL, Robinson D, Shield JP, Temple K, Ellard S, Hattersley AT: Mutations in ATPsensitive $\mathrm{K}+$ channel genes cause transient neonatal diabetes and permanent diabetes in childhood or adulthood. Diabetes 2007;56: 1930-1937, erratum in Diabetes 2008;57:523.

25 Edghill EL, Flanagan SE, Patch AM, Boustred C, Parrish A, Shields B, Shepherd MH, Hussain K, Kapoor RR, Malecki M, MacDonald MJ, Støy J, Steiner DF, Philipson LH, Bell GI, Neonatal Diabetes International Collaborative Group, Hattersley AT, Ellard S: Insulin mutation screening in 1,044 patients with diabetes: mutations in the INS gene are a common cause of neonatal diabetes but a rare cause of diabetes diagnosed in childhood or adulthood. Diabetes 2008;57:1034-1042.

26 Gloyn AL, Pearson ER, Antcliff JF, Proks P, Bruining GJ, Slingerland AS, Howard N, Srinivasan S, Silva JM, Molnes J, Edghill EL, Frayling TM, Temple IK, Mackay D, Shield JP, Sumnik Z, van Rhijn A, Wales JK, Clark P, Gorman S, Aisenberg J, Ellard S, Njølstad PR, Ashcroft FM, Hattersley AT: Activating mutations in the gene encoding the ATP-sensitive potassium-channel subunit Kir6.2 and permanent neonatal diabetes. N Engl J Med
2004;350:1838-1849, erratum in N Engl J Med 2004;351:1470.

27 Gloyn AL, Reimann F, Girard C, Edghill EL, Proks P, Pearson ER, Temple IK, Mackay DJ, Shield JP, Freedenberg D, Noyes K, Ellard S, Ashcroft FM, Gribble FM, Hattersley AT: Relapsing diabetes can result from moderately activating mutations in KCNJ11. Hum Mol Genet 2005;14:925-934.

28 Babenko AP, Polak M, Cavé H, Busiah K, Czernichow P, Scharfmann R, Bryan J, Aguilar-Bryan L, Vaxillaire M, Froguel P: Activating mutations in the $\mathrm{ABCC} 8$ gene in neonatal diabetes mellitus. N Engl J Med 2006;355:456-466.

29 Clark RH, McTaggart JS, Webster R, Mannikko R, Iberl M, Sim XL, Rorsman P, Glitsch M, Beeson D, Ashcroft FM: Muscle dysfunction caused by a $\mathrm{K}_{\mathrm{ATP}}$ channel mutation in neonatal diabetes is neuronal in origin. Science 2010;329:458-461.

30 Gloyn AL, Diatloff-Zito C, Edghill EL, Bellanné-Chantelot C, Nivot S, Coutant R, Ellard S, Hattersley AT, Robert JJ: KCNJ11 activating mutations are associated with developmental delay, epilepsy and neonatal diabetes syndrome and other neurological features. Eur J Hum Genet 2006;14:824-830.

31 Ellard S, Flanagan SE, Girard CA, Patch AM, Harries LW, Parrish A, Edghill EL, Mackay DJ, Proks P, Shimomura K, Haberland $\mathrm{H}$, Carson DJ, Shield JP, Hattersley AT, Ashcroft FM: Permanent neonatal diabetes caused by dominant, recessive, or compound heterozygous SUR1 mutations with opposite functional effects. Am J Hum Genet 2007;81:375-382.

- 32 Pearson ER, Flechtner I, Niølstad PR, Malecki MT, Flanagan SE, Larkin B, Ashcroft FM, Klimes I, Codner E, Iotova V, Slingerland AS, Shield J, Robert JJ, Holst JJ, Clark PM, Ellard S, Søvik O, Polak M, Hattersley AT, Neonatal Diabetes International Collaborative Group: Switching from insulin to oral sulfonylureas in patients with diabetes due to Kir6.2 mutations. N Engl J Med 2006;355:467-477.

33 Rafiq M, Flanagan SE, Patch AM, Shields BM, Ellard S, Hattersley AT, Neonatal Diabetes International Collaborative Group: Effective treatment with oral sulfonylureas in patients with diabetes due to sulfonylurea receptor 1 (SUR1) mutations. Diabetes Care 2008;31:204-209.

- 34 Klupa T, Skupien J, Mirkiewicz-Sieradzka B, Gach A, Noczynska A, Zubkiewicz-Kucharska A, Szalecki M, Kozek E, Nazim J, Mlynarski W, Malecki MT: Efficacy and safety of sulfonylurea use in permanent neonatal diabetes due to KCNJ11 gene mutations: 34-month median follow-up. Diabetes Technol Ther 2010;12:387-391.

35 Slingerland AS, Nuboer R, Hadders-Algra M, Hattersley AT, Bruining GJ: Improved motor development and good long-term glycaemic control with sulfonylurea treatment in a patient with the syndrome of intermediate developmental delay, early-onset generalised epilepsy and neonatal diabetes associated with the V59M mutation in the KCNJ11 gene. Diabetologia 2006;49:2559-2563. 
36 Gurgel LC, Crispim F, Noffs MH, Belzunces E, Rahal MA, Moisés RS: Sulfonylrea treatment in permanent neonatal diabetes due to G53D mutation in the KCNJ11 gene: improvement in glycemic control and neurological function. Diabetes Care 2007; 30:e108.

- 37 Koster JC, Cadario F, Peruzzi C, Colombo C, Nichols CG, Barbetti F: The G53D mutation in Kir6.2 (KCNJ11) is associated with neonatal diabetes and motor dysfunction in adulthood that is improved with sulfonylurea therapy. J Clin Endocrinol Metab 2008;93:10541061.

- 38 Støy J, Edghill EL, Flanagan SE, Ye H, Paz VP, Pluzhnikov A, Below JE, Hayes MG, Cox NJ, Lipkind GM, Lipton RB, Greeley SA, Patch AM, Ellard S, Steiner DF, Hattersley AT, Philipson LH, Bell GI, Neonatal Diabetes International Collaborative Group: Insulin gene mutations as a cause of permanent neonatal diabetes. Proc Natl Acad Sci USA 2007;104: 15040-15044

- 39 Polak M, Dechaume A, Cavé H, Nimri R, Crosnier H, Sulmont V, de Kerdanet M, Scharfmann R, Lebenthal Y, Froguel P, Vaxillaire M, French ND (Neonatal Diabetes) Study Group: Heterozygous missense mutations in the insulin gene are linked to permanent diabetes appearing in the neonatal period or in early infancy: a report from the French ND (Neonatal Diabetes) Study Group. Diabetes 2008;57:1115-1119.

40 Colombo C, Porzio O, Liu M, Massa O, Vasta M, Salardi S, Beccaria L, Monciotti C, Toni S, Pedersen O, Hansen T, Federici L, Pesavento R, Cadario F, Federici G, Ghirri P, Arvan P, Iafusco D, Barbetti F, Early Onset Diabetes Study Group of the Italian Society of Pediatric Endocrinology and Diabetes (SIEDP): Seven mutations in the human insulin gene linked to permanent neonatal/infancy-onset diabetes mellitus. J Clin Invest 2008;118:21482156.

-41 Molven A, Ringdal M, Nordbø AM, Raeder H, Støy J, Lipkind GM, Steiner DF, Philipson LH, Bergmann I, Aarskog D, Undlien DE, Joner G, Søvik O, Norwegian Childhood Diabetes Study Group, Bell GI, Njølstad PR: Mutations in the insulin gene can cause MODY and autoantibody-negative type 1 diabetes. Diabetes 2008;57:1131-1135.

42 Støy J, Greeley SA, Paz VP, Ye H, Pastore AN, Skowron KB, Lipton RB, Cogen FR, Bell GI, Philipson LH, United States Neonatal Diabetes Working Group: Diagnosis and treatment of neonatal diabetes: a United States experience. Pediatr Diabetes 2008;9:450-459.

43 Russo L, Iafusco D, Brescianini S, Nocerino V, Bizzarri C, Toni S, Cerutti F, Monciotti C, Pesavento R, Iughetti L, Bernardini L, Bonfanti R, Gargantini L, Vanelli M, Aguilar-Bryan L, Stazi MA, Grasso V, Colombo C, Barbetti F, ISPED Early Diabetes Study Group: Permanent diabetes during the first year of life: multiple gene screening in 54 patients. Diabetologia 2011;54:1693-1701.
44 Rubio-Cabezas O, Patch AM, Minton JA, Flanagan SE, Edghill EL, Hussain K, Balafrej A, Deeb A, Buchanan CR, Jefferson IG, Mutair A, Neonatal Diabetes International Collaborative Group, Hattersley AT, Ellard S: Wolcott-Rallison syndrome is the most common genetic cause of permanent neonatal diabetes in consanguineous families. J Clin Endocrinol Metab 2009;94:4162-4170, erratum in J Clin Endocrinol Metab 2010;95: 1480

45 Habeb AM, Al-Magamsi MS, Eid IM, Ali MI, Hattersley AT, Hussain K, Ellard S: Incidence, genetics, and clinical phenotype of permanent neonatal diabetes mellitus in northwest Saudi Arabia. Pediatr Diabetes DOI: 10.1111/j.1399-5448.2011.00828.x.

46 Temple IK, Gardner RJ, Mackay DJ, Barber JC, Robinson DO, Shield JP: Transient neonatal diabetes: widening the understanding of the etiopathogenesis of diabetes. Diabetes 2000;49:1359-1366.

-47 Temple IK, Shield JP: Transient neonatal diabetes, a disorder of imprinting. J Med Genet 2002;39:872-875.

48 Mackay DJ, Boonen SE, Clayton-Smith J, Goodship J, Hahnemann JM, Kant SG, Njølstad PR, Robin NH, Robinson DO, Siebert R, Shield JP, White HE, Temple IK: A maternal hypomethylation syndrome presenting as transient neonatal diabetes mellitus. Hum Genet 2006;120:262-269.

49 Mackay DJ, Callaway JL, Marks SM, White HE, Acerini CL, Boonen SE, Dayanikli P, Firth HV, Goodship JA, Haemers AP, Hahnemann JM, Kordonouri O, Masoud AF, Oestergaard E, Storr J, Ellard S, Hattersley AT, Robinson DO, Temple IK: Hypomethylation of multiple imprinted loci in individuals with transient neonatal diabetes is associated with mutations in ZFP57. Nat Genet 2008;40:949951.

50 Docherty LE, Kabwama S, Lehmann A, Hawke E, Harrison L, Flanagan SE, Ellard S, Hattersley AT, Shield JP, Ennis S, Mackay DJ, Temple IK: Clinical presentation of 6q24 transient neonatal diabetes mellitus (6q24 TNDM) and genotype-phenotype correlation in an international cohort of patients. Diabetologia 2013;56:758-762.

51 Shield JP, Temple IK, Sabin M, Mackay D, Robinson DO, Betts PR, Carson DJ, Cavé H, Chevenne D, Polak M: An assessment of pancreatic endocrine function and insulin sensitivity in patients with transient neonatal diabetes in remission. Arch Dis Child Fetal Neonatal Ed 2004;89:F341-F343.

52 Shield JP: Neonatal diabetes: how research unravelling the genetic puzzle has both widened our understanding of pancreatic development whilst improving children's quality of life. Horm Res 2007;67:77-83.

53 Rubio-Cabezas O, Edghill EL, Argente J, Hattersley AT: Testing for monogenic diabetes among children and adolescents with antibody-negative clinically defined Type 1 diabetes. Diabet Med 2009;26:1070-1074.
54 Allen HL, Flanagan SE, Shaw-Smith C, De Franco E, Akerman I, Caswell R, International Pancreatic Agenesis Consortium, Ferrer J, Hattersley AT, Ellard S: GATA6 haploinsufficiency causes pancreatic agenesis in humans. Nat Genet 2011;44:20-22.

55 De Franco E, Shaw-Smith C, Flanagan SE, Shepherd MH, International NDM Consortium, Hattersley AT, Ellard S: GATA6 mutations cause a broad phenotypic spectrum of diabetes from pancreatic agenesis to adultonset diabetes without exocrine insufficiency. Diabetes 2013;62:993-997.

56 Smith SB, Qu HQ, Taleb N, Kishimoto NY, Scheel DW, Lu Y, Patch AM, Grabs R, Wang J, Lynn FC, Miyatsuka T, Mitchell J, Seerke R, Désir J, Eijnden SV, Abramowicz M, Kacet N, Weill J, Renard ME, Gentile M, Hansen I, Dewar K, Hattersley AT, Wang R, Wilson ME, Johnson JD, Polychronakos C, German MS: Rfx6 directs islet formation and insulin production in mice and humans. Nature 2010;463:775-780.

57 Rubio-Cabezas O, Minton JA, Kantor I, Williams D, Ellard S, Hattersley AT: Homozygous mutations in NEUROD1 are responsible for a novel syndrome of permanent neonatal diabetes and neurological abnormalities. Diabetes 2010;59:2326-2331.

58 Rubio-Cabezas O, Jensen JN, Hodgson MI, Codner E, Ellard S, Serup P, Hattersley AT: Permanent neonatal diabetes and enteric anendocrinosis associated with biallelic mutations in NEUROG3. Diabetes 2011;60:13491353.

-59 Solomon BD, Pineda-Alvarez DE, Balog JZ, Hadley D, Gropman AL, Nandagopal R, Han JC, Hahn JS, Blain D, Brooks B, Muenke M: Compound heterozygosity for mutations in PAX6 in a patient with complex brain anomaly, neonatal diabetes mellitus, and microophthalmia. Am J Med Genet A 2009; 149A:2543-2546.

60 Poulton CJ, Schot R, Kia SK, Jones M, Verheijen FW, Venselaar $\mathrm{H}$, de Wit MC, de Graaff E, Bertoli-Avella AM, Mancini GM: Microcephaly with simplified gyration, epilepsy, and infantile diabetes linked to inappropriate apoptosis of neural progenitors. Am J Hum Genet 2011;89:265-276.

61 Greeley SA, John PM, Winn AN, Ornelas J, Lipton RB, Philipson LH, Bell GI, Huang ES: The cost-effectiveness of personalized genetic medicine: the case of genetic testing in neonatal diabetes. Diabetes Care 2011;34:622-627.

62 Barrett TG: Differential diagnosis of type 1 diabetes: which genetic syndromes need to be considered? Pediatr Diabetes 2007;8(suppl 6):15-23.

63 Slingerland AS, Hattersley AT: Activating mutations in the gene encoding Kir6.2 alter fetal and postnatal growth and also cause neonatal diabetes. J Clin Endocrinol Metab 2006; 91:2782-2788.

-64 Baumeister FA, Engelsberger I, Schulze A: Pancreatic agenesis as cause for neonatal diabetes mellitus. Klin Padiatr 2005;217:76-81. 
65 Bennett K, James C, Mutair A, Al-Shaikh H, Sinani A, Hussain K: Four novel cases of permanent neonatal diabetes mellitus caused by homozygous mutations in the glucokinase gene. Pediatr Diabetes 2011;12:192-196.

66 Garin I, Edghill EL, Akerman I, Rubio-Cabezas O, Rica I, Locke JM, Maestro MA, Alshaikh A, Bundak R, del Castillo G, Deeb A, Deiss D, Fernandez JM, Godbole K, Hussain K, O'Connell M, Klupa T, Kolouskova S, Mohsin F, Perlman K, Sumnik Z, Rial JM, Ugarte E, Vasanthi T, Neonatal Diabetes International Group, Johnstone K, Flanagan SE, Martínez R, Castaño C, Patch AM, Fernández-Rebollo E, Raile K, Morgan N, Harries LW, Castaño L, Ellard S, Ferrer J, Perez de Nanclares G, Hattersley AT: Recessive mutations in the INS gene result in neonatal diabetes through reduced insulin biosynthesis. Proc Natl Acad Sci USA 2010;107:3105-3110.
67 Ellard S, Lango Allen H, De Franco E, Flanagan SE, Hysenaj G, Colclough K, Houghton JA, Shepherd M, Hattersley AT, Weedon MN, Caswell R: Improved genetic testing for monogenic diabetes using targeted next-generation sequencing. Diabetologia 2013;56: 1958-1963.

68 Karges B, Meissner T, Icks A, Kapellen T, Holl RW: Management of diabetes mellitus in infants. Nat Rev Endocrinol 2011;8:201211.

69 Tubiana-Rufi N: Insulin pump therapy in neonatal diabetes. Endocr Dev 2007;12:6774.
70 Codner E, Flanagan S, Ellard S, García H, Hattersley AT: High-dose glibenclamide can replace insulin therapy despite transitory diarrhea in early-onset diabetes caused by a novel R201L Kir6.2 mutation. Diabetes Care 2005; 28:758-759.

77 Kumaraguru J, Flanagan SE, Greeley SA, Nuboer R, Støy J, Philipson LH, Hattersley AT, Rubio-Cabezas O: Tooth discoloration in patients with neonatal diabetes after transfer onto glibenclamide: a previously unreported side effect. Diabetes Care 2009;32:14281430.

72 Rubio-Cabezas O, Flanagan SE, Edghill EL, Patch A-M, Ellard S, Hattersley AT: Parental consanguinity strongly influences genetic aetiology in permanent neonatal diabetes. 35 th ISPAD Annu Conf, Ljubljana, September 2009. 